\title{
FIRST RESULTS FROM THE GRONINGEN AMS FACILITY
}

\author{
JOHANNES VAN DER PLICHT, ANITA AERTS, STEF WIJMA and ALBERT ZONDERVAN
}

Centre for Isotope Research, University of Groningen, Nijenborgh 4, NL-9747 AG Groningen The Netherlands

\begin{abstract}
A new generation accelerator mass spectrometer has been installed at the Centre for Isotope Research in Groningen, The Netherlands. It is a dedicated ${ }^{14} \mathrm{C}$ machine, with a capacity of measuring 3000 samples per year with high precision $(<0.5 \%)$. The system has been in full operation since the summer of 1994 . We present here a short summary of the
results and performance obtained thus far.
\end{abstract}

\section{INTRODUCTION}

After four decades of operating a low-background laboratory for ${ }^{14} \mathrm{C}$ measurements (with, at present, 9 counters (van der Plicht et al. 1992), the University of Groningen acquired an accelerator mass spectrometer (AMS). This AMS is the second machine of the new generation high-throughput and fully automated spectrometer, dedicated to ${ }^{14} \mathrm{C}$ analysis (Purser 1990; Purser et al. 1990). It is built by High Voltage Engineering Europa in Amersfoort, The Netherlands. The first technical reports and full system descriptions are given elsewhere (Mous et al. 1994; Gottdang et al. 1995). The system consists of a 59-sample ion source, a recombinator as injector, a $2.5 \mathrm{MV}$ tandetron accelerator, a high-energy mass spectrometer $\left(110^{\circ}\right.$ magnet, $33^{\circ}$ electrostatic deflector and a $90^{\circ}$ magnet $)$ and a $\Delta \mathrm{E} / \mathrm{E}$ ionization chamber.

To obtain the required high precision in ${ }^{14} \mathrm{C}$, the three carbon isotopes $\left({ }^{12} \mathrm{C},{ }^{13} \mathrm{C},{ }^{14} \mathrm{C}\right)$ are accelerated simultaneously. This ensures a continuous diagnostic tool, wherein the three isotopes travel along the same path, thereby minimizing mass fractionation.

The Groningen AMS has been in full operation since the summer of 1994. Here we present the results obtained during the first weeks of operation.

\section{RESUltS}

The results obtained thus far can be divided into three data sets: 1) performance/acceptance test results, 2) comparison of AMS and conventional results of the same sample material; and 3) unknown samples.

1. Performance Test - Results of the performance test taken on ANU sucrose targets clearly show that a precision below $0.5 \% \mathrm{pMC}$ is obtainable on a routine basis. (For details, see Gottdang, Mous and van der Plicht (1995)).

2. Comparison with Conventional Results - In the first weeks after we acquired the machine, extensive tests were performed on samples with a well-known radiocarbon content. The results are summarized in Table 1 . For a variety of materials, ${ }^{13} \mathrm{C}$ and ${ }^{14} \mathrm{C}$ results are listed for both conventional (proportional gas counters for ${ }^{14} \mathrm{C}$, and conventional mass spectrometry for ${ }^{13} \mathrm{C}$ ) and AMS.

Four IAEA intercomparison standards (Rozanski et al. 1992) were measured: C2 (travertine), C3 (cellulose), C5 (wood) and C6 (ANU sucrose). The data listed for these materials are our laboratory values (and not the IAEA "consensus" values as reported in Rozanski et al. (1992). The other measurements, listed in order of increasing age, are results from regular samples submitted to our conventional laboratory, which we used for cross-checking our AMS. All ${ }^{14} \mathrm{C}$ activities are cor- 
rected for isotopic fractionation with $\delta^{13} \mathrm{C}$; for the marine samples, the ages stated are corrected for a reservoir effect of $400 \mathrm{yr}$.

The ${ }^{14} \mathrm{C}$ activities (in pMC) are shown graphically in Figure 1. In the top part of Figure 1, the AMS and conventional activities are plotted against each other, showing excellent agreement. To show the deviations between AMS and conventional, the difference between the activities measured both ways (also in pMC) is plotted in the bottom part of Figure 1. From the latter, we deduce that the "internal" error for the series of measurements shown ranges from $0.2-0.5 \mathrm{pMC}$, whereas the "external" error is better than ca. $0.6 \mathrm{pMC}$. The "external" errors are the error bars shown. The most significant contribution to this error in the data set shown is statistical (typically $0.2 \mathrm{pMC}$ for a modern sample). The mean value for the values plotted in Figure 1 (bottom) is $-0.17 \pm 0.13$.

3. Unknown Samples - After installation of the AMS system and extensive cross-checking with conventional measurements, we were able to start measuring unknown samples, from our own projects-e.g., wiggle-match dating of peat bogs (Kilian et al. 1994)-and those of our laboratory's users. The laboratory identifier for the Groningen AMS is GrA; GrN will be retained for conventional measurements.

TABLE 1. Comparison of ${ }^{13} \mathrm{C}$ and ${ }^{14} \mathrm{C}$ Results Between the Groningen Conventional and AMS Laboratories

\begin{tabular}{|c|c|c|c|c|c|c|c|c|}
\hline \multirow[b]{2}{*}{ Sample } & \multicolumn{3}{|c|}{ Conventional } & \multirow[b]{2}{*}{$\begin{array}{l}\text { Age } \\
\text { (BP) }\end{array}$} & \multicolumn{4}{|c|}{ AMS } \\
\hline & $\begin{array}{l}\text { GrN- } \\
\text { no. }\end{array}$ & $\begin{array}{l}\delta^{13} \mathrm{C} \\
(\% 0)\end{array}$ & $\begin{array}{c}14 \mathrm{a} \\
(\mathrm{pMC})\end{array}$ & & GrA- no. & $\begin{array}{l}\delta^{13} \mathrm{C} \\
(\% 0)\end{array}$ & $\begin{array}{c}14 \mathrm{a} \\
(\mathrm{pMC})\end{array}$ & $\begin{array}{l}\text { Age } \\
\text { (BP) }\end{array}$ \\
\hline $\begin{array}{l}\mathrm{C} 2 \\
\text { travertine }\end{array}$ & 17638 & -8.22 & 41.04(0.07) & $7154(14)$ & $\begin{array}{l}298,299 \\
418,425\end{array}$ & -10.3 & $41.32(0.37)$ & $7100(28)$ \\
\hline $\begin{array}{l}\text { C3 } \\
\text { cellulose }\end{array}$ & 17639 & -24.68 & $129.30(0.12)$ & -- & $\begin{array}{l}300,301 \\
139\end{array}$ & -24.9 & $129.87(0.48)$ & -- \\
\hline $\begin{array}{l}\text { C5 } \\
\text { wood }\end{array}$ & 17777 & -24.89 & $23.03(0.06)$ & $11,796(20)$ & $\begin{array}{l}302,303,409 \\
416,417\end{array}$ & -26.7 & $23.23(0.38)$ & $11,725(130)$ \\
\hline $\begin{array}{l}\text { C6 } \\
\text { sucrose }\end{array}$ & 17641 & -10.38 & $149.82(0.13)$ & -- & $\begin{array}{l}269,270,271, \\
272,410\end{array}$ & -10.2 & $150.36(0.41)$ & -- \\
\hline $\begin{array}{l}\text { Cirebon D } \\
\text { wood }\end{array}$ & 20516 & -26.25 & $97.50(0.11)$ & 204(9) & 187 & -24.5 & $97.18(0.18)$ & $230(15)$ \\
\hline $\begin{array}{l}\text { Cirebon C } \\
\text { wood }\end{array}$ & 20515 & -25.15 & $96.69(0.13)$ & $270(11)$ & 185,186 & -24.9 & $96.24(0.21)$ & $308(18)$ \\
\hline $\begin{array}{l}\text { Kyrkberget } \\
\text { bone }\end{array}$ & 20685 & -21.03 & $88.44(0.12)$ & $990(10)$ & 462 & -20.2 & $88.66(0.26)$ & $967(23)$ \\
\hline $\begin{array}{l}\text { Hope E.* } \\
\text { crab }\end{array}$ & 20169 & -10.66 & $82.75(0.34)$ & $1521(33)$ & 156 & -8.4 & $82.05(0.39)$ & 1589(38) \\
\hline $\begin{array}{l}\text { Wijnaldum* } \\
\text { shell }\end{array}$ & 19689 & -0.64 & $73.66(0.32)$ & $2456(33)$ & 158 & -1.5 & $74.36(0.37)$ & $2379(40)$ \\
\hline $\begin{array}{l}\text { Norman E.* } \\
\text { shell }\end{array}$ & 20158 & +1.01 & $60.84(0.38)$ & $3992(48)$ & 160 & +0.8 & $61.16(0.32)$ & $3950(42)$ \\
\hline $\begin{array}{l}\text { Rijswijk A4* } \\
\text { shell }\end{array}$ & 20286 & -6.75 & $47.75(0.22)$ & $5938(36)$ & 154 & -4.3 & $48.21(0.28)$ & $5860(45)$ \\
\hline $\begin{array}{l}\text { Pavlov } \\
\text { charcoal }\end{array}$ & 20391 & -25.64 & $3.84(0.21)$ & $26,170(450)$ & 208,209 & -23.8 & $4.10(0.21)$ & $25,660(400)$ \\
\hline
\end{tabular}

* 400-yr reservoir effect subtracted in age calculation 


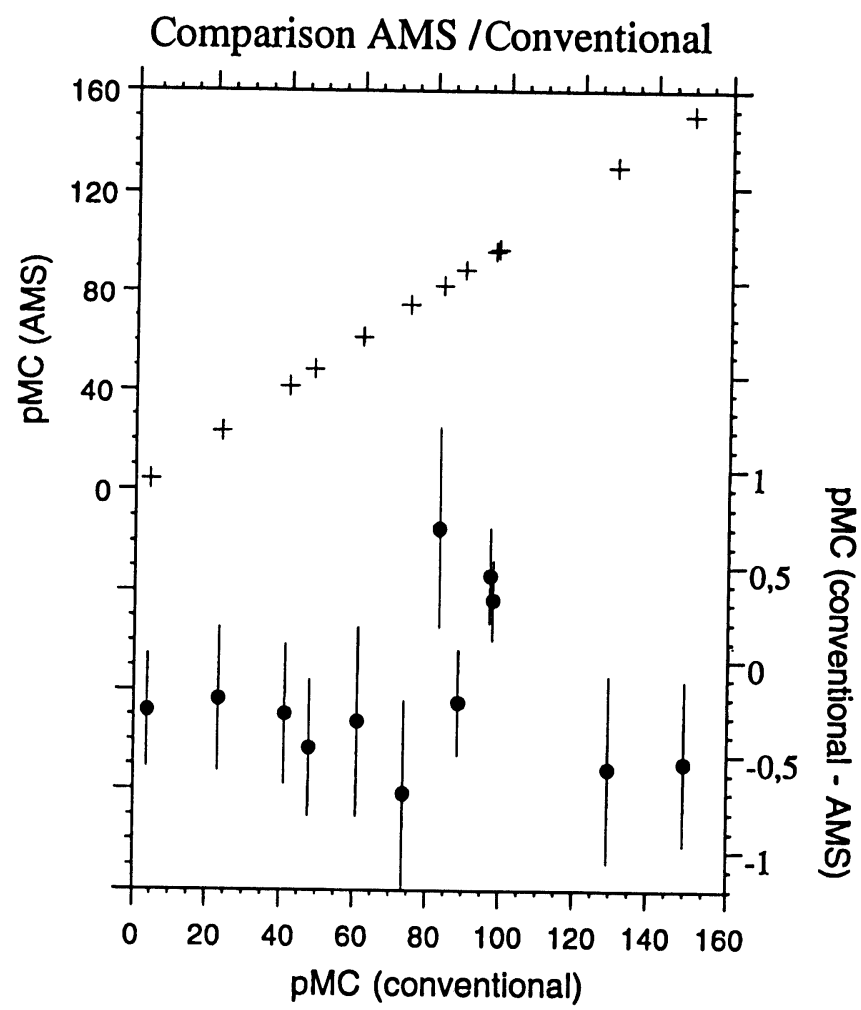

Fig. 1. Top. ${ }^{14} \mathrm{C}$ activities in pMC for AMS (y-axis) and conventional (x-axis) measurements. Bottom. ${ }^{14} \mathrm{C}$ activity difference between AMS and conventional measurements.

\section{TARGETS}

The graphite is produced by reducing $\mathrm{CO}_{2}$ with hydrogen under a Fe-catalyst, more or less the "standard procedure" described by Vogel et al. (1987). Before graphitization, the Fe powder is pre-reduced with hydrogen. We use 325 mesh iron powder, with a $\mathrm{C}: \mathrm{Fe}$ ratio of $1: 1$. The water is trapped at $-18^{\circ} \mathrm{C}$ by Peltier elements. (More detailed description and performance studies, was given by Heerschop et al. (1994)). The graphite is pressed in a $2-\mathrm{mm}$ diameter hole in the aluminium target holders that are placed in the carousel of the ion source. The carousel can contain up to 59 target holders.

Once placed in the ion source, the target is rastered; 8 different positions on the target are sputtered in order to avoid cratering and thus possible serious fractionation effects.

\section{BACKGROUND}

The background level is, at present, $45 \mathrm{ka}$ or $\mathrm{ca} .0 .2 \%$. This includes the target preparation, which is clearly the limiting factor. Since the first weeks of operation this number has slowly been improving. Preparations to make measurements of old samples possible are under way (using, e.g., a semi-clean room and special graphite rigs for such samples).

The background contribution of the AMS system (without considering target preparation) is negligible, as can be concluded from Figure 2, the bottom part of which shows a spectrum from a so- 
called "machine blank" target. This is a special aluminium target holder with a flat sputtering surface, without graphite. The peak at channel 100 is not related to the AMS, but is generated by $\alpha$-particles from a ${ }^{241} \mathrm{Am}$ source, which we placed in the detector chamber for testing purposes. The counts beyond channel 120 can be considered as background from the AMS system. There is only one count observed in the ${ }^{14} \mathrm{C}$ part of the spectrum during several hours running time. This makes it hard to calculate the background contribution from the AMS system, which is, however, certainly better than $100 \mathrm{ka}$.

A spectrum for an ANU-sucrose target is shown in the top of Figure 2. There is a window set in the detector electronics as indicated. Both spectra (top and bottom of Fig. 2) are from the E-detector and represent counts of $c a .30 \mathrm{~min}$.

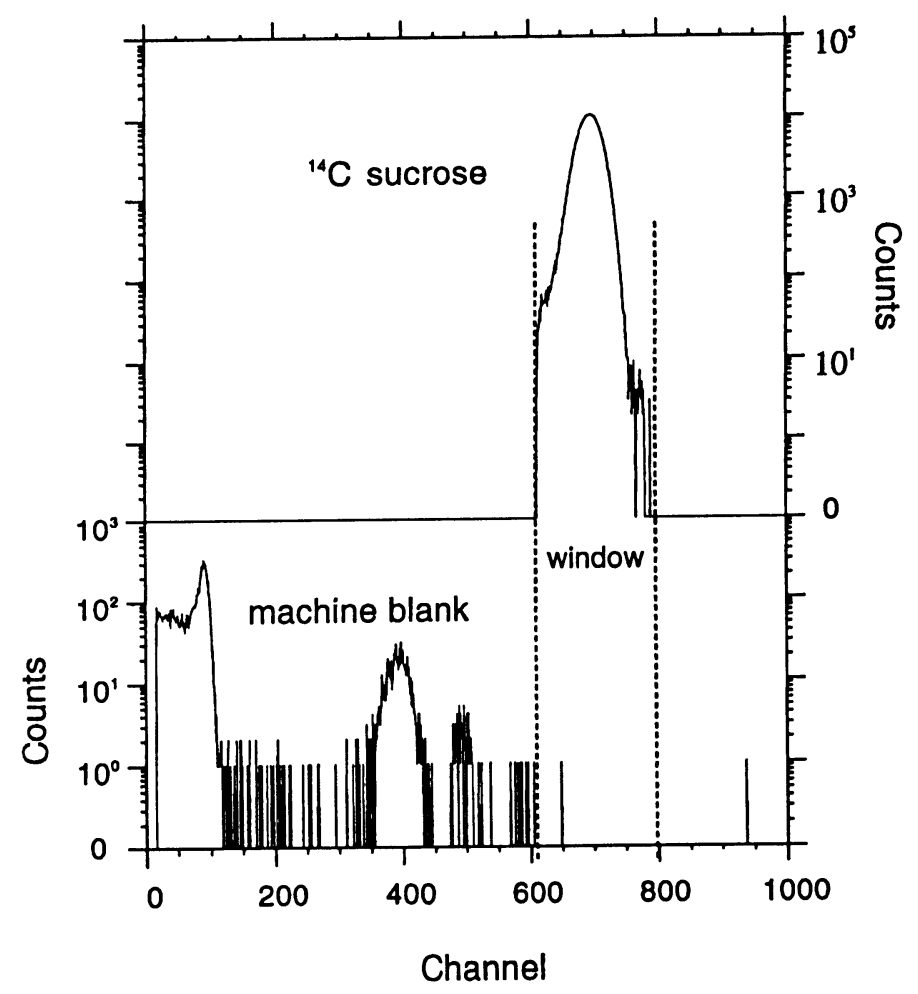

Fig. 2. Top. Energy spectrum (gated), measured for an ANU-sucrose target. Bottom. Energy spectrum, measured for a machine blank. An $\alpha$-emitting source is present in the detector chamber.

\section{ConClusion}

The Groningen AMS is now fully operational. It is a high-throughput mass spectrometer, dedicated for ${ }^{14} \mathrm{C}$. Both extensive test measurements on modern samples (ANU sucrose) and comparison with conventionally measured samples (proportional gas counters) show that a precision better than $0.5 \%$ (pMC) is obtainable. In the first year of operation, we expect to measure $c a .1000$ samples by AMS (GrA), roughly equal to the amount of conventional samples ( $\mathrm{GrN}$ ) measured annually. 


\section{REFERENCES}

Gottdang, A., Mous, D. J. W. and van der Plicht, J. 1995 The HVEE ${ }^{14} \mathrm{C}$ system at Groningen. Radiocarbon, this issue.

Heerschop, J., Aerts, A. T., Meijer, H. A. J. and Zondervan, A. (ms.) 1994 Fractionation effects in preparing graphite for AMS. Poster presented at the 15th International ${ }^{14} \mathrm{C}$ Conference, Glasgow, Scotland, 15-19 August.

Kilian, M. R., van Geel, B. and van der Plicht, J. (ms.) 1994 Wiggle-match dating of Holocene raised bog deposits. Poster presented at the 15 th International ${ }^{14} \mathrm{C}$ Conference, Glasgow, Scotland, 15-19 August.

Mous, D. J. W., Gottdang, A. and van der Plicht, J. 1994 Status of the first HVEE ${ }^{14} \mathrm{C}$ AMS in Groningen. In Fifield, L. K., Fink, D., Sie, S. H. and Tuniz, C., eds., Proceedings of the Sixth International Conference on Accelerator Mass Spectrometry. Nuclear Instruments and Methods in Physics Research B92: 12-15.

van der Plicht, J., Streurman, H. J. and Schreuder, G. R. 1992 A new data acquisition system for the Groningen counters. In Long, A. and Kra, R. S., eds., Proceedings of the 14th International ${ }^{14} \mathrm{C}$ Conference. Radiocarbon 34(3): 500-505.

Purser, K. H. 1990 A high throughput ${ }^{14} \mathrm{C}$ Accelerator Mass Spectrometer. In Long, A. and Kra, R. S., eds., Proceedings of the 14th International ${ }^{14} \mathrm{C}$ Conference. Radiocarbon 34(3): 459-467.

Purser, K. H., Smick, T. H. and Purser, R. K. 1990 A precision ${ }^{14} \mathrm{C}$ accelerator mass spectrometer. In Yiou, $\mathrm{F}$. and Raisbeck, G. M., eds., Proceedings of the Fifth International Conference on Accelerator Mass Spectrometry. Nuclear Instruments and Methods in Physics Research B52: 263-268.

Rozanski, K., Stichler, W., Gonfiantini, R., Scott, E. M., Beukens, R. P., Kromer, B. and van der Plicht, J. 1992 The IAEA ${ }^{14} \mathrm{C}$ intercomparison exercise. In Long, A. and Kra, R. S., eds., Proceedings of the 14th International ${ }^{14} \mathrm{C}$ Conference. Radiocarbon 34(3): 506-519.

Vogel, J. S., Nelson, D. E. and Southon, J. R. $1987{ }^{14} \mathrm{C}$ background levels in an accelerator mass spectrometry system. Radiocarbon 29(3): 323-333. 